\title{
MODEL PENGEMBANGAN EKONOMI MASYARAKAT PESISIR BERBASIS CO-MANAGEMENT SUMBERDAYA PERIKANAN DI KABUPATEN PONTIANAK
}

\author{
Witarsa \\ Universitas Tanjungpura, Indonesia \\ Email: witnessedu@yahoo.com
}

\begin{abstract}
Abstrak: Model Pengembangan Ekonomi Masyarakat Pesisir Berbasis CoManagement Sumberdaya Perikanan di Kabupaten Pontianak. Penelitian ini bertujuan mengidentifikasi komponen urgen pengelolaan sumberdaya pesisir, faktorfaktor internal dan eksternal, dan peringkat prioritas co-management sumberdaya perikanan. Metode yang digunakan adalah PRA (Participatory Rural Appraisal), SWOT (Strength, Weaknesses, Opportunities, and Treats), dan alur pikir PMPK (pemecahan masalah dan pengambilan keputusan). Hasil penelitian menunjukkan bahwa banyak permasalahan yang ditemukan pengelolaan sumberdaya pesisir khususnya dilihat dari aspek biofisik, teknologi, market, sosial ekonomi, dan kelembagaan.
\end{abstract}

Kata kunci: ekonomi masyarakat pesisir, co-management, sumberdaya perikanan

\begin{abstract}
Fisheries Resources Co-Management Based Model of Coastal Community Economic Development in Pontianak. The purpose of this study is to determine the common problems faced by coastal communities by identifying important component of coastal resource management, internal and external factors, and the priority scale for fisheries resources co-management. This study employs three methods, namely Participatory Rural Appraisal (PRA), Strengths, Weaknesses, Opportunities, and Treats Analysis (SWOT), and a Problem-solving and Decision-making. The results show that the problems are found on managing coastal resource, especially in the biophysical, technological, market, social economic, and institutional aspect.
\end{abstract}

Keywords: economy of coastal communities, co-management, fishery resources

\section{PENDAHULUAN}

Pesatnya perkembangan wilayah pesisir dan sumberdaya laut di Kabupaten Pontianak Kalimantan Barat pada posisi strategis akan menghasilkan keuntungan ekonomi berupa devisa hasil ekspor, namun juga telah memberikan efek negatif terhadap perairan, terutama wilayah pesisir dan laut itu sendiri. Kontribusi yang demikian akan terus berlangsung, apalagi terdapat berbagai aktivitas masyarakat yang tidak sesuai dengan kemampuan dan daya dukung lingkungan, seperti kegiatan perikanan tangkap, budidaya perikanan, dan industri pariwisata yang berbagai aktivitasnya hanya mengejar keuntungan ekonomi semata. Berbagai upaya pemanfaatan harus dilakukan secara terencana dan tepat, agar dapat memberikan manfaat bagi kesejahteraan terutama terakomodasinya kesejahteraan masyarakat pesisir.

Pembangunan ekonomi masyarakat pesisir pada kecamatan yang terletak di wilayah pantai Kabupaten Pontianak Kalimantan Barat hendaknya dilakukan sebagai suatu proses sosial yaitu pertama perubahan yang terjadi terus menerus. 
Kedua usaha meningkatkan pendapatan ekonomi masyarakat dengan implikasi menaikkan pendapatan per kapita yang terus berlangsung dalam jangka panjang. Ketiga, perbaikan dan atau penataan sistem kelembagaan di berbagai bidang (ekonomi, sosial, hukum, politik, budaya, dan lain-lain) terutama dari aspek perbaikan organisasi dan regulasi. Dengan demikian pembangunan ekonomi di wilayah pesisir harus dipandang sebagai suatu mekanisme di mana saling keterkaitan dan saling mempengaruhi antara faktor-faktor yang menyebabkan terjadinya pembangunan ekonomi di daerah tersebut (Lembaga Survey dan Kajian Kalimantan Barat, 2013)

Hasil kajian Lembaga Survey dan Kajian Kalimantan Barat, 2013 bahwa pertumbuhan ekonomi di Kalimantan Barat yang terus meningkat justru tidak linier dengan peningkatan pendapatan masyarakat pesisir, sehingga berbagai komoditi ekonomi hasil laut yang sangat potensial seperti berbagai jenis ikan yang bisa diolah menjadi dendeng, abon, kerupuk, bakso, ikan asin, ikan teri, dan udang ebi, budi daya ikan dan rumput laut serta komoditi lain belum memberikan kontribusi nilai ekonomi masyarakat pesisir yang signifikan dengan komoditi sumber laut. Kondisi ini tidak mencerminkan fenomena seperti adanya pertumbuhan ekonomi yang tinggi tetapi tidak disertai dengan ketidakselarasan pendapatan sosial yang tinggi. Meningkatnya investasi tetapi pengangguran justru tidak berkurang. Meningkatnya anggaran pembangunan tetapi kemiskinan dan ketertinggalan, merupakan kenyataan yang tidak dapat dipungkiri.
Dari hasil survey terhadap jumlah penduduk di Kecamatan Mempawah Hilir yang berjumlah 56.612 orang (laki-laki sebanyak 28.594 orang, perempuan sebanyak 28.018), di mana sebagian besar atau 68 persen dari jumlah penduduk lakilaki bekerja sebagai nelayan, sedangkan sisanya 32 persen bekerja pada sektor lain. Sementara 79 persen penduduk wanita bekerja sambilan membantu suami, berjualan dan lain.

Carlssona (2005) menyatakan bahwa ketika ekonom melihat organisasi ekonomi secara keseluruhan mereka kemudian mengajukan banyak pertanyaan tentang efisiensi. Namun, selama beberapa dekade, ekonom tidak bertanya tentang biaya dan manfaat dari menurunnya atau kerusakan lingkungan (modal alam) wilayah pesisir laut akibat kegiatan proses produksi. Hal ini juga dapat mengakibatkan suatu kondisi di mana kegiatan produktif melebihi kemampuan ekosistem untuk mendukung produksi ekonomi. Ketika batas ekologi terlampaui dari waktu ke waktu, sebuah kesulitan sosial akhirnya dapat terjadi melalui runtuhnya sumber daya terkait seperti perikanan. Spektrum yang luas dari informasi tentang proses ekosistem, kesehatan, manfaat dan nilai-nilai ekonomi pesisir sangat penting dikelola dengan baik dan benar dalam mempertahankan modal alam di wilayah pesisir untuk kepentingan generasi sekarang dan mendatang.

Tujuan penelitian (1) untuk mengetahui permasalahan umum yang dihadapi masyarakat pesisir di Kabupaten Pontianak. (2) Mengetahui komponen urgen pengelolaan sumberdaya pesisir, Mengidentifikasi faktor-faktor internal yang 
mempengaruhi pemberdayaan masyarakat pesisir, (4) Mengidentifikasi faktor-faktor eksternal yang mempengaruhi pemberdayaan masyarakat pesisir, (5) Mengidentifikasi Peringkat prioritas comanagement sumberdaya perikanan.

Ekonomi masyarakat pesisir merupakan kegiatan pengelolaan sumberdaya pesisir dan masyarakat yang tinggal di wilayah tersebut. Pengaturan wilayah Pesisir dan Pulau-Pulau Kecil pada tahun 2011, Mahkamah Konstitusi (2010:164-165) menyatakan bahwa hak pengusahaan perairan pesisir bertentangan dengan UUD Negara Republik Indonesia Tahun 1945. Hak ini dikhawatirkan akan mengakibatkan wilayah perairan pesisir dikuasai oleh pemodal besar, sehingga nelayan tradisional yang telah menggantungkan kehidupannya pada sumber daya pesisir akan tersingkir. Menurut Mahkamah Konstitusi, salah satu tujuan pengelolaan wilayah pesisir dan pulau-pulau kecil adalah memperkuat peran serta masyarakat dan lembaga pemerintah serta mendorong inisiatif masyarakat dalam pengelolaan sumberdaya pesisir dan pulaupulau kecil agar tercapai keadilan, keseimbangan dan berkelanjutan.

Dalam pengusahaan perairan pesisir, menurut Suseno (201:27-8) terdapat beberapa aspek yang perlu diperhatikan, yaitu aspek sosial, perikanan, jasa-jasa lingkungan, dan keseimbangan lingkungan hidup. Keseimbangan aspek ekonomi, sosial dan lingkungan hidup dalam proses pembangunan adalah prinsip yang senantiasa harus menjadi dasar utama bagi seluruh stakeholder. Secara umum prinsip pengelolaan sumber daya meliputi empat hal, yaitu 1) prinsip kehati-hatian. Hal ini termasuk dalam Code of Conduct for Responsible Nature 1995, yang menyebutkan negara harus memberlakukan pendekatan yang bersifat kehati-hatian secara luas demi konservasi, pengelolaan, dan pengusahaan sumber daya hayati guna melindungi dan mengawetkan lingkungannya, 2) prinsip tanggung Jawab, pengelolaan yang bertanggung jawab tidak memperbolehkan hasil tangkapan melebihi jumlah potensi lestari yang boleh ditangkap, 3) prinsip Keterpaduan, yaitu keterpaduan antara pemerintah pusat, pemerintah daerah, dunia usaha dan masyarakat dalam proses perencanaan, pelaksanaan dan pengawasan dalam pengelolaan dan pemanfaatan sumber daya, 4) prinsip Berkelanjutan yaitu konsep pembangunan berkelanjutan adalah pembangunan yang mengintegrasikan komponen ekologi, ekonomi dan sosial. Setiap komponen itu saling berhubungan dalam satu sistem yang dipicu kekuatan dan tujuan.

Alasan pentingnya tujuan pengelolaan ekonomi pesisir bahwa ekonomi ekologi meneliti hubungan antara ekosistem, ekonomi, dan kesejahteraan manusia. Hal ini bisa dibilang salah satu daerah yang paling cepat berkembang dalam bidang ekonomi. Sweeden et al (2008) menyatakan pemahaman ekonomi pesisir memberikan kontribusi ekonomi penting dari ekosistem untuk perekonomian karena beberapa alasan. Pertama, ekosistem pesisir yang sangat produktif dan memberikan kontribusi sejumlah besar nilai ekonomi terhadap perekonomian pesisir. Kedua, semua negara pada umumnya, dan ekonomi pesisir khususnya, memiliki sistem yang kompleks dari kepemilikan, pasar, organisasi produktif, 
dan pemerintah yang menentukan siapa yang menerima manfaat ekonomi dan yang membayar biaya produksi.

Carlssona (2005) menyatakan,"comanagement, or the joint management of the commons, is often formulated in terms of some arrangement of power sharing between the State and a community of resource users. In reality, there often are multiple local interests and multiple government agencies at play, and comanagement can hardly be understood as the interaction of a unitary State and a homogeneous community". (Berkes 1998:12). Singleton (1998:7) menyatakan, "co-management as the term given to governance systems that combine state control with local, decentralized decision making and accountability and which, ideally, combine the strengths and mitigate the weaknesses of each". Grazia et al (2007) menyatakan, "co-management a situation in which two or more social actors negotiate, define and guarantee amongst themselves a fair sharing of the management functions, entitlements and responsibilities for a given territory, area or set of natural resources".

Arifin (2004:6) menyatakan comanagement memadukan antara unsur masyarakat pengguna (kelompok nelayan, pengusaha perikanan, dll) dan pemerintah yang menghindari peran dominan yang berlebihan dari satu pihak dalam pengelolaan sumberdaya pesisir dan laut sehingga pembiasaan aspirasi pada satu pihak dapat dieliminasi. Dalam jangka panjang, pelaksanaan co-management ini diyakini akan memberikan perubahanperubahan ke arah yang lebih baik yaitu: 1$)$ meningkatkan kesadaran masyarakat akan pentingnya sumberdaya pesisir dan laut dalam menunjang kehidupan, 2) meningkatkan kemampuan masyarakat, sehingga mampu berperan serta dalam setiap tahapan pengelolaan secara terpadu, 3) meningkatkan pendapatan masyarakat dengan bentuk-bentuk pemanfaatan yang lestari dan berkelanjutan serta berwawasan lingkungan.

Seperti yang dikatakan oleh Cundill dan Christo (2009) co-management is a relationship between a resource-user group and another organization or entity (usually a government agency) for the purposes of fisheries management in which some degree of responsibility and/or authority is conferred to both parties. Co-management presupposes that parties have, in a formal or semi-formal way, agreed on a process for sharing management rights and responsibilities. But getting to comanagement involves institution building, the development of trust and social capital, and generally a long voyage on a bumpy road. Co-management emerges out of extensive deliberation and negotiation, and the actual arrangement itself evolves over time.

Menjamin keadilan dan berkelanjutan sumberdaya perikanan perlu diperhatikan untuk menjaga ekosistem pesisir. Luky dan Dede (2009:41) menyatakan one of the key factors in understanding the dynamics between fishers, fish farmers and the economic and social environment is the concept of fishing rights. Prior to introducing a fisheries co-management arrangement, and in order to ensure fairness and sustainability in the management of fishing 
communities, the rights-based fisheries concept must be considered.

Agus et al (2010:2) menegaskan secara alamiah, pengelolaan sistem perikanan tidak dapat dilepaskan dari tiga dimensi yang tidak terpisahkan satu sama lain yaitu (1) dimensi sumberdaya perikanan dan ekosistemnya; (2) dimensi pemanfaatan sumberdaya perikanan untuk kepentingan sosial ekonomi masyarakat; dan (3) dimensi kebijakan perikanan itu sendiri. Terkait dengan tiga dimensi tersebut, pengelolaan perikanan saat ini masih belum mempertimbangkan keseimbangan ketiga dimensi tersebut, di mana kepentingan pemanfaatan untuk kesejahteraan sosial ekonomi masyarakat dirasakan lebih besar dibanding dengan misalnya kesehatan ekosistemnya. Dengan kata lain, pendekatan yang dilakukan masih parsial belum terintegrasi dalam sebuah batasan ekosistem yang menjadi wadah dari sumberdaya ikan sebagai target pengelolaan. Dalam konteks inilah, pendekatan terintegrasi melalui pendekatan ekosistem terhadap pengelolaan perikanan (ecosystem approach to fisheries) menjadi sangat penting.

A. Muluk et al (2009) menyatakan Hirarki Co-Management Perikanan muncul karena adanya berbagai kemungkinan proses pengambilan keputusan yang melibatkan masyarakat lokal dan pemerintah. Terdapat 3 hal yang menentukan variasi bentuk CoManagement serta hirarkinya yaitu: (1) Peranan pemerintah dan masyarakat dalam pengambilan keputusan; (2) Bentuk tugas dan fungsi manajemen yang dapat atau akan dikelola bersama oleh pemerintah dan masyarakat atau didistribusikan di antara kedua pihak; (3) tahapan proses manajemen ketika secara aktual kerjasama pengelolaan betul-betul terwujud (sebagai contoh, pada tahapan perencanaan, implementasi atau evaluasi).

\section{METODE}

Jenis penelitian adalah penelitian partisipatif. Lokasi penelitian di Kecamatan Sungai Kunyit dan Kecamatan Mempawah Hilir, dan Kecamatan Mempawah Timur. Subjek penelitian 26 kelompok nelayan dengan jumlah anggota 473 orang.

Teknik pengumpulan data yang digunakan dalam studi ini adalah kombinasi instrumen langsung dan tidak langsung, serta studi dokumenter. Kombinasi instrumen langsung berupa wawancara terstruktur dengan masyarakat nelayan dan atau masyarakat pesisir yang mengikutsertakan tenaga penyuluh dan penanggung jawab perikanan dan kelautan di Kecamatan Mempawah Hilir, Kecamatan Mempawah Timur, dan Kecamatan Sungai Kunyit, Tim Pengawas, Ketua Persatuan Nelayan, dan pihak Kelurahan. Kombinasi instrumen pengumpulan data tidak langsung berupa kuesioner yang berisi Kunci Model Pengembangan Ekonomi Masyarakat Berbasis Ko-Manajemen Sumberdaya Perikanan yang dilakukan dengan cara membagikan dan menjelaskan materi kuesioner. Studi dokumenter dilakukan dengan cara mencari, mengumpulkan data melalui dokumen dan literatur yang relevan dengan pemberdayaan ekonomi masyarakat pesisir berbasis co-management. Hasil pengumpulan data bertujuan membantu dalam: (1) Inventarisasi data, konsultasi publik, dan survey potensi sumberdaya berdasarkan aspek biogeofisik, sosial 
ekonomi, dan budaya. (2) Identifikasi permasalahan yang mungkin timbul dan berdampak langsung pada pemberdayaan ekonomi masyarakat pesisir berbasis comanagement.(3) Analisis dan sintesis data dan informasi dalam upaya pemberdayaan ekonomi masyarakat pesisir berbasis comanajemen.

Data yang akan dikumpulkan dalam pekerjaan ini dikelompokkan menjadi 4 (empat) bagian, yaitu (1) Data Biofisik, (3) Data Teknologi, (3) Data Pasar, dan (4) Data Sosial-Ekonomi Budaya. Kedua kelompok data diperoleh, baik dari pengamatan di lapangan maupun dari data sekunder yang didapatkan dan publikasi lembaga yang relevan. Langkah-langkah proses menjaring data penelitian dikelompokkan menjadi 4 (empat) bagian, yaitu (1) Data Biofisik, (3) Data Teknologi, (3) Data Pasar, dan (4) Data Sosial-Ekonomi Budaya. Kedua kelompok data diperoleh, baik dari pengamatan di lapangan maupun dari data sekunder yang didapatkan dan publikasi lembaga yang relevan.

Sesuai dengan ilustrasi Gambar 1, dapat dinyatakan, bahwa jenis dan jumlah data yang akan dihimpun ditentukan menurut kebutuhan penggunaan dalam pekerjaan ini yaitu sebagai basis informasi dalam perencanaan pengembangan ekonomi mayarakat pesisir berbasis ko-manajemen sumber daya perikanan, serta pembangunan sumber daya manusia secara optimal dan berkelanjutan dengan cara menentukan sebagian dan kawasan pesisir di Kabupaten Pontianak pengembangan ekonomi mayarakat pesisir berbasis co-management sumber daya perikanan
Metode yang digunakan dalam kegiatan ini adalah PRA (Participatory Rural Appraisal), SWOT (Strength, Weaknesses, Opportunities, and Treats), dan alur pikir PMKP (pemecahan masalah dan pengambilan keputusan). PRA bila diartikan secara harfiah adalah pengkajian/ pemahaman keadaan desa secara partisipatif, artinya PRA merupakan cara yang digunakan dalam melakukan kajian untuk memahami keadaan desa dengan melihat partisipasi masyarakat. Dengan menerjemahkan secara harfiah menunjukkan adanya kelemahan PRA. Teknik PRA sebenarnya alat pembelajaran masyarakat untuk meneliti keadaannya sendiri di mana proses belajar tersebut diterapkan melalui kegiatan bersama (ARMPII Badan Litbang Pertanian dan PSW-UGM, 2000). Melihat istilah PRA, semua orang akan mempunyai persepsi yang sama bahwa luas sasaran mencakup satu wilayah kecamatan. Bagaimana seandainya kelompok sasaran tersebut lebih dipersempit, seperti halnya pada kajian ini yaitu berdasarkan kelompok (bidang penangkapan, pengolahan, pengumpul dan pemasaran, pengolahan hasil perikanan).

Salah satu teknik yang dikembangkan dalam proses pemecahan masalah dan pengambilan keputusan adalah SWOT. Halhal yang perlu dilakukan dalam SWOT adalah mengidentifikasi faktor internal (kekuatan dan kelemahan) dan faktor eksternal (peluang dan ancaman), membuat strategi kebijakan dari kombinasi keempat faktor yang mempengaruhi. Strategi S-O, yaitu memaksimumkan kekuatan dan peluang; strategi W-O, yaitu meminimumkan kelemahan dan memaksimumkan peluang; 


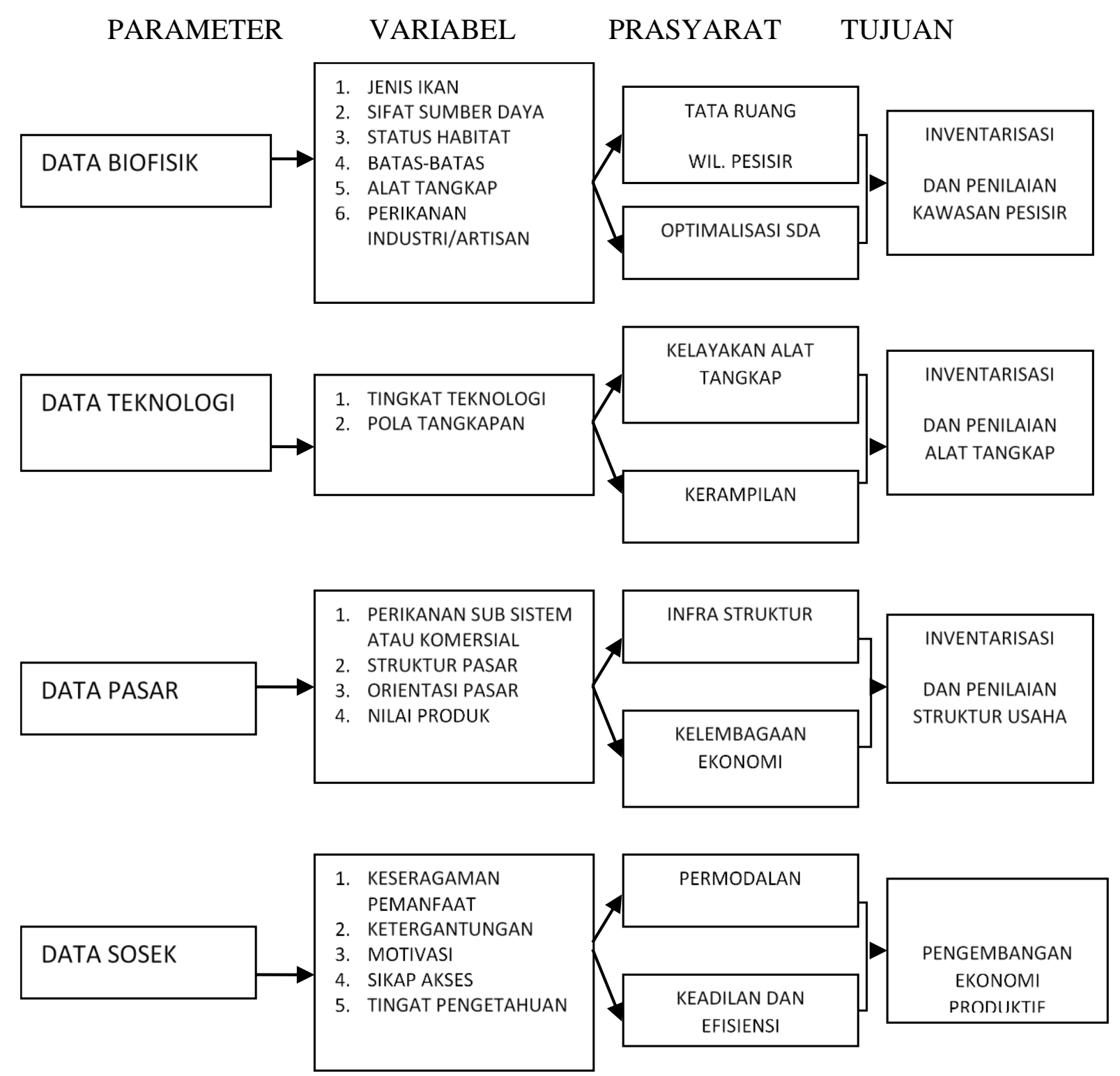

Gambar 1. Langkah-Langkah Proses Menjaring Data Penelitian

strategi S-T, yaitu memaksimumkan kekuatan dan meminimumkan ancaman; strategi WT, yaitu meminimumkan kelemahan dan ancaman. Keempat strategi tersebut jika disederhanakan akan menjadi dua, yaitu memaksimumkan faktor pendorong (SO) dan meminimumkan faktor penghambat (WT).

Selanjutnya untuk lebih memepertajam dalam pemecahan masalah dan pengambilan keputusan digunakan alur pikir PMKP (pemecahan masalah dan pengambilan keputusan) seperti yang telah dirumuskan oleh Nies, SUK. (2000). Alur pikir PMKP adalah sebagai berikut: (1) identifikasi masalah, (2) analisa masalah-masalah, (3) perumusan masalah, (4) analisa masalah, (5) analisa alternatif pemecahan masalah, (6) pemilihan alternatif pemecahan masalah, (7) keputusan pilihan pemecahan masalah, (8) rencana pelaksanaan hasil pemecahan masalah, (9) menjamin sukses pelaksanaan.

Pengembangan ekonomi masyarakat pesisir di Pengembangan Ekonomi Masyarakat Pesisir berbasis Ko-Manajemen Sumberdaya Perikanan di Kecamatan Sungai 
Kunyit, Kecamatan Mempawah Hilir, dan Kecamatan Mempawah Timur di Kabupaten Pontianak juga memperhatikan aspek pendukung yaitu kegiatan yang berwawasan lingkungan, sehingga dalam survey dan kajian disertakan pentingnya Mangrove.

Nilai penting komunitas hutan mangrove digunakan untuk memberikan deskripsi mengenai fungsi suatu jenis tumbuhan mangrove dalam komunitasnya. Untuk mendapatkan nilai penting, terlebih dahulu dilakukan pengambilan contoh untuk mendapatkan data mengenai jenis, jumlah tegakan, dan diameter pohon.

Data tersebut kemudian dianalisis lebih lanjut untuk mendapatkan kerapatan jenis, frekuensi jenis, luas penutupan, dan nilai penting jenis, dengan rumusan-rumusan sebagai berikut:

(i) Kerapan Jenis (D) adalah jumlah tegakan jenis i dalam suatu unit area, dengan rumusan

$$
D i=n_{i} / A
$$

Di mana

Di $=$ Kerapatan Jenis $\mathrm{i}$

$\mathrm{n}$ = Jumlah Total Tegakan dan jenis $\mathrm{i}$

$A=$ Luas total Areal pengambilan contoh (luas total petak plot)

(ii) Kerapan Relatif Jenis (RDi) adalah perbandingan antara jumlah tegakan jenis i (ni) dan jumlah total tegakan seluruh jenis $(Z n)$, dengan rumus:

$$
R D i=\left(n_{i} / \sum n\right) \times 100
$$

(iii) Frekuensi Jenis (Fi) adalah peluang ditemukannya jenis i dalam petak contoh/plot yang diamati, dengan rumus:

$$
F i=p i / \sum p
$$

Di mana
$\mathrm{Fi}=$ Frekuensi Jenis $\mathrm{i}$

pi = Jumlah petak contoh plot di mana ditemukan jenis i dan

$\Sigma \mathrm{p}=$ Jumlah total petak contoh/plot yang diamati

(iv) Frekuensi Relatif Jenis (RFi) adalah perbandingan antara frekuensi jenis i (Fi) dan jumlah frekuensi untuk seluruh jenis $(\Sigma F)$, dengan rumus

$\mathrm{RFi}=(\mathrm{Fi} / \Sigma \mathrm{F}) \times 100$

(v) Penutupan Jenis (Ci) adalah luas penutupan jenis i dalam suatu unit area, dengan rumus:

$$
\mathrm{Ci}=\sum \mathrm{BA} / \mathrm{A}
$$

Di mana

$\mathrm{BA}=\pi \mathrm{DBH}^{2} / 4\left(\right.$ dalam $\left.\mathrm{Cm}^{2}\right)$

$\pi=3,1416$ adalah (konstanta dalam $\mathrm{DBH}$ ) diameter pohon dan jenis $\mathrm{i}$

$A=$ Luas total areal pengambilan contoh

$\mathrm{DBH}=\mathrm{CBH} / \pi$ (dalam cm), $\mathrm{CBH}$ adalah lingkaran pohon setinggi dada.

(vi) Penutupan Relatif Jenis ( $\mathrm{RCi}$ ) adalah perbandingan antara luas areal penutupan jenis i ( $\mathrm{Ci}$ ) dan luas total Area penutupan untuk seluruh jenis $(\Sigma C)$, dengan rumus:

$\mathrm{RCi}=(\mathrm{Ci} / \Sigma \mathrm{C}) \times 100$

Jumlah nilai Kerapatan Relatif Jenis (RDi), Frekuensi Relatif Jenis (RFi), dan Penutupan jenis (RCi) menunjukkan Nilai Penting Jenis (IVi), dengan rumus:

$$
\mathrm{IVi}=\mathrm{RDi}+\mathrm{RFi}+\mathrm{RCi}
$$

Nilai penting suatu jenis berkisar antara 0 300.

\section{HASIL PEMBAHASAN}

Berdasarkan analisis informasi wilayah kecamatan Mempawah timur, serta identifikasi faktor-faktor eksternal dan 
internal masyarakat pesisir, selanjutnya dilakukan analisis SWOT. Lingkungan eksternal setiap saat berubah dengan cepat sehingga berpotensi menimbulkan berbagai ancaman baik yang datang dari pesaing utama maupun dari lingkungan bisnis yang senantiasa berubah. Konsekuensi perubahan faktor eksternal tersebut akan mengakibatkan perubahan faktor internal masyarakat pesisir, seperti perubahan pada kekuatan maupun kelemahan yang telah dimiliki. Kemudian dilakukan evaluasi paramater merupakan faktor yang sangat penting untuk mengukur berbagai potensi sumberdaya yang dimiliki wilayah pesisir di Kabupaten Pontianak, dengan tujuan agar indikator faktor strategi eksternal dan faktor strategi internal dapat diidentifikasi secara tepat.

Hasil EFAS (External Strategic Factors Analysis) dan IFAS (Internal Strategic Factors Analysis) yaitu Hasil analisis pada level komponen SWOT, menunjukkan bahwa komponen weaknesses menempati urutan teratas dalam program pemberdayaan masyarakat pesisir, yang kemudian diikuti oleh beberapa level komponen SWOT yang lain, yaitu threats, strength, dan opportunities. Dari hasil analisis tersebut dapat disimpulkan bahwa program pemberdayaan masyarakat pesisir mempunyai kelemahan dan tantangan yang besar jika dibandingkan dengan peluang dan kekuatannya.

Faktor-faktor kelemahan (weaknesses) dalam pemberdayaan masyarakat pesisir jumlahnya cukup banyak, namun kelemahan yang paling utama adalah kualitas sumberdaya masyarakat pesisir yang rendah. Sedangkan faktor ancaman utama dalam pemberdayaan masyarakat pesisir adalah adanya penetapan prioritas pembangunan sektor perikanan, yang seringkali, lebih rendah apabila dibandingkan dengan sektor lainnya. Bagaimanapun akhir-akhir ini pemerintah terhadap pemberdayaan masyarakat pesisir telah menunjukkan perhatian yang cukup meningkat dibandingkan dengan waktu sebelumnya.

Sedangkan faktor kekuatan pemberdayaan masyarakat pesisir adalah masih banyaknya masyarakat pesisir, yaitu nelayan, pembudidaya, pengolah dan pedagang ikan, yang perlu diberdayakan baik dari aspek ekonomi, sosial dan politik. Sementara itu, faktor yang paling rendah adalah faktor peluang dalam kaitannya dengan pemberdayaan. Meskipun demikian, perhatian pemerintah yang cukup tinggi terhadap pemberdayaan masyarakat pesisir ini merupakan peluang yang paling utama. Dari hasil analisis tersebut menunjukkan bahwa pemberdayaan masyarakat pesisir masih sangat bergantung kepada dukungan pemerintah, walaupun peluang pendanaan dari pihak lain masih banyak, misalnya dana dari Pembinaan Usaha Kecil dan Koperasi Badan Usaha Milik Negara (PUKK BUMN) dan dari swasta

Konsep pelaksanaan pemberdayaan masyarakat pesisir dilakukan melalui pendekatan wilayah. Konsep ini dapat dikatakan merupakan konsep kombinasi dari beberapa program dalam suatu wilayah dan setiap program yang dilakukan dapat saling terkait antara satu program dengan program yang lain. Hal ini dikarenakan, pada suatu wilayah, dapat saja mempunyai beberapa permasalahan dan setiap permasalahan 
dapat diselesaikan secara terpadu dan terintegrasi.

Berdasarkan komponen data yang dijumpai di lapangan melalui EFAS (External Strategic Factors Analysis) dan IFAS (Internal Strategic Factors Analysis), kemudian dilakukan analisis hasil berdasarkan instrumen survey sebagai berikut:

1. Aspek biofisik meliputi perikanan multispesies atau unispesies, sifat sumberdaya ikan, tingkat ekploitasi sumberdaya, status habitas, batasbatas, perikanan alat tunggal atau jamak, perikanan industri atau artisan (buatan).

2. Aspek teknologi yang meliputi tingkat teknologi, dan pola penangkapan ikan.

3. Aspek pasar yang mencakup perikanan sub sistem atau komersial, struktur pasar, orientasi pasar, dan nilai produk.

4. Aspek sosial ekonomi budaya pemegang kepentingan yang mencakup keseraman pemanfaatan sumberdaya, ketergantungan pada perikanan sebagai sumber nafkah, sikap nelayan, dan tingkat informasi atau pengetahuan tentang perikanan dan penglolaannya.

Dari Tabel 1, dapat dilihat bahwa tingkatan biofisik di Kecamatan Sungai Kunyit, Kecamatan Mempawah Hilir, dan Kecamatan Mempawah Timur adalah sebagai berikut:

1. Jenis ikan yang di tangkap pada ketiga wilayah studi memang beragam atau multispesies yaitu antara $11-20$ jenis ikan.

2. Dilihat dari gugusan pulau-pulau kecil, ada sumber daya ikan yang cenderung tidak bermigrasi terutama udang, sedangkan ikan kembung, tongkol, tenggiri, bawal, ukan kakap merah atau ikan lain cenderung bermigrasi terutama pada bulan-bulan tertentu yang hasil tangkapan menurun. Hal ini bisa dilihat dari fluktuasi hasil tangkapan yang berfluktuasi berkisar 5-15 persen.

3. Tingkat eksploitasi hasil tangkapan cukup baik yaitu ada peningkatan, walaupun masih di bawah 59 persen. Upaya peningkatan hasil tangkapan juga cukup baik yaitu dengan cara menambah waktu melaut, memperbaiki alat tangkap dan mengetahui lokasi ikan berdasarkan pengalaman nelayan. Pendugaan stock sulit dilakukan karena hasil tangkapan yang telah disortir langsung didistribusikan ke pasar sekitar, Pontianak, dan Sanggau, serta belum didukung oleh cool storage.

4. Status habitat di lokasi studi bisa dikategorikan masih cukup baik, walaupun pemanfaatan hutan bakau belum optimal dilakukan.

Mendukung hasil penelitian Dinas Perikanan dan Kelautan Kabupaten Pontianak tahun 2007, bahwa ekosistem sumberdaya pesisir tentang alternatif penentuan kawasan di wilayah perairan pesisir dan Puiau-Pulau Kecil Kecamatan Sungai Kunyit dan Kecamatan Mempawah Hulu yang peruntukannya diprioritaskan sebagai Kawasan Konservasi Laut Daerah Kabupaten Pontianak adalah kawasan yang memiliki beberapa kriteria sebagai berikut (1) memiliki ekosistem terumbu karang dengan keanekaragaman yang lebih bervariasi, namun dalam kondisi rentan dengan perilaku destruktif oleh oknum nelayan yang tidak bertanggung jawab, (2) 
Tabel 1. Aspek Biofisik Kecamatan Sungai Kunyit, Kecamatan Mempawah Hilir, dan Kecamatan Mempawah Timur

\begin{tabular}{|c|c|c|c|c|}
\hline \multirow[t]{2}{*}{ Atribut } & \multirow[t]{2}{*}{ Indikator } & \multicolumn{3}{|c|}{$\begin{array}{c}\text { Tingkatan } \\
\text { Aspek Biofisik }\end{array}$} \\
\hline & & 1 & 2 & 3 \\
\hline $\begin{array}{l}\text { Perikanan } \\
\text { multispesies } \\
\text { atau } \\
\text { unispesies }\end{array}$ & Spesies jenis ikan apa yang ditangkap & & 2 & \\
\hline $\begin{array}{l}\text { Sumberdaya } \\
\text { berimigrasi } \\
\text { atau menetap }\end{array}$ & Sumberdaya ikan menetap atau bermigrasi & & 2 & \\
\hline $\begin{array}{l}\text { Tingkat } \\
\text { Eksploitasi } \\
\text { sumberdaya }\end{array}$ & $\begin{array}{l}\text { 1. Hasil tangkapan meningkat atau menurun } \\
\text { 2. Upaya meningkatkan hasil tangkapan } \\
\text { 3. Hasil untuk pendugaan stock ikan }\end{array}$ & 1 & $\begin{array}{l}2 \\
2 \\
\end{array}$ & \\
\hline Status habitat & $\begin{array}{l}\text { 1. Persentase karang hidup } \\
\text { 2. Sumberdaya ikan dan tumbuhan laut bisa } \\
\text { disebut sehat. } \\
\text { 3. Air telah mengalami polusi } \\
\text { 4. Pemanfaatan hutan bakau }\end{array}$ & 1 & 2 & 3 \\
\hline Batas-batas & $\begin{array}{l}\text { 1. Batas geografis untuk suatu perikanan } \\
\text { 2. Penentuan batas-batas tersebut } \\
\text { 3. Ketentuan siapa menangkap ikan dalam } \\
\text { batasan tertentu untuk produksi } \\
\text { 4. Bagaimana batasan penangkapan ikan } \\
\text { ditentukan. } \\
\text { 5. Batasan lain yang relevan dengan batas } \\
\text { penangkapan } \\
\text { 6. Cara menentukan batasan relevan tsb. }\end{array}$ & & $\begin{array}{l}\text { delum } \\
\text { defir }\end{array}$ & \\
\hline $\begin{array}{l}\text { Perikanan Alat } \\
\text { Tunggal atau } \\
\text { jamak }\end{array}$ & $\begin{array}{l}\text { 1. Jenis alat tangkap ikan yang digunakan } \\
\text { 2. Kecenderungan perkembangan alat-alat } \\
\text { tangkap tersebut }\end{array}$ & 1 & 2 & \\
\hline $\begin{array}{l}\text { Perikanan } \\
\text { Industri atau } \\
\text { artisan } \\
\text { (buatan) }\end{array}$ & $\begin{array}{l}\text { 1. Tipe kapal dan alat tangkap ikan yang } \\
\text { digunakan } \\
\text { 2. Struktur alat tangkap dan kapal } \\
\text { 3. Dapatkan perikanan dibagai menjadi industri } \\
\text { dan artisanal } \\
\text { 4. Cara melakukan industri dan artisanal } \\
\end{array}$ & $\begin{array}{l}1 \\
1 \\
1\end{array}$ & 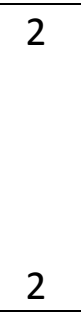 & \\
\hline
\end{tabular}

Ekosistem terumbu karang pada lokasi alternatif secara faktual telah mengalami degradasi, namun ada sebagian yang masih dalam kondisi alami dengan tutupan yang terkategori baik, (3) Ekosistem terumbu karang alternatif kawasan konservasi memiliki kelimpahan sumberdaya perikanan karang yang beragam dan melimpah dan kondisinya masih baik, namun mengandung potensi kepunahan apabila tidak dilakukan upaya perlindungan, (4) ekosistem dan kawasan yang dijadikan sebagai lokasi alternatif juga merupakan lokasi mendarat dan bertelurnya spesies yang mendapatkan 
prioritas perlindungan, seperti penyu Laut dan atau ekosistem sumberdaya yang terkategori unik, (5) Ekosistem dan kawasan alternatif yang dilindungi Memiliki bentang alam yang berasosiasi dengan habitat (flora dan fauna) dan masih relatif cukup terbebas dan aktivitas manusia yang beragam dan kompleks, (6) Ekosistem yang dijadikan sebagai alternatif konservasi bertolak dari ketentuan yang berlaku dan mendapatkan dukungan dari komunitas nelayan yang menjadikan alternatif kawasan konservasi sebagai daerah tangkap (fishing ground), (7) Faktor pendukung penentuan alternatif lokasi sebagai kawasan yang dilindungi berorientasi pada fungsi dan arahan peruntukan lahan yang telah ditetapkan dalam Rencana Tata Ruang Wilayah Pesisir, baik dalam skala Provinsi Kalimantan Barat maupun Kabupaten Pontianak. Alternatif ini didasarkan pada kondisi bahwa sampai saat ini ekosistem terumbu karang di perairan Pulau Dato dan Pulau Setinjang beserta spesies Penyu yang masih seringkali ditemukan nelayan, sesuai dengan kriteria biota dan ekosistem yang layak mendapatkan upaya perlindungan, saat ini dalam kondisi terancam. Apabila tidak dilindungi akan berpotensi untuk mengalami degradasi yang lebih parah dan bahkan kepunahan bagi spesies dimaksud, terutama di wilayah pesisir dan laut Kecamatan Mempawah Hilir dan Sungai Kunyit, Kabupaten Pontianak.

1. Batas walayah penangkapan yang belum terdefinisi. Batas wilayah ini sangat penting terutama untuk mengatasi konflik apabila budaya tangkap semakin maju dan modern, dan agar nelayan bisa mengetahui secara jelas area lokasi penangkapan, serta bisa menjaga perairan secara bersama jika ada kapal penangkap asing yang masuk ke batas wilayah tangkapan.

2. Pada perikanan tunggal atau jamak, nelayan menggunakan jenis alat tangkap yang beragam yaitu gill net nylon dan plastik, bubu/pancing, papayang, pukat cincin, jaring insang, bagan perahu rakit, long line, pancing lain/rawai dan lainnya. Alat tangkap yang digunakan diketiga lokasi studi cenderung sama.

3. Pada perikanan industri atau artisan (buatan), nelayan menggunakan tipe kapal yang beragam berupa kapal motor 0-5 gt, kapal motor lebih 0-5 gt, namun ada nelayan yang menggunakan sampan tanpa mesin. Struktur alat tangkap dihitung dalam satuan ton. Di Kecamatan Sungai Kunyit hasil tangkapan berjumlah 206,2 ton, di Kecamatan Mempawah Hilir hasil tangkapan berjumlah 26.268,65 ton, dan di Kecamatan Mempawah Timur hasil tangkapan berjumlah 1.214 ton. Hasil tangkapan akan menambah nilai ekonomi jika ada industri cool storage dan industri pengalengan ikan. Sifat industri perikanan berpeluang melalui budi daya tambak, sebab ketiga lokasi studi yaitu Kecamatan Sungai Kunyit luas areal tambak $79 \mathrm{Ha}$, di Kecamatan Mempawah Hilir areal tambak seluas 194 $\mathrm{Ha}$, dan Kecamatan Mempawah Timur luas areal tambak $86 \mathrm{Ha}$.

Dari Tabel 2, dapat dilihat bahwa tingkatan teknologi di Kecamatan Sungai Kunyit, Kecamatan Mempawah Hilir, dan Kecamatan Mempawah Timur adalah sebagai berikut: 
Tabel 2. Aspek Teknologi Di Kecamatan Sungai Kunyit, Kecamatan Mempawah Hilir, dan Kecamatan Mempawah Timur

\begin{tabular}{|c|c|c|c|c|}
\hline \multirow{2}{*}{ tribut } & \multirow{2}{*}{ Indikator } & \multicolumn{3}{|c|}{ Tingkat Teknologi } \\
\hline & & 1 & 2 & 3 \\
\hline $\begin{array}{l}\text { Tingkat } \\
\text { Teknologi }\end{array}$ & $\begin{array}{l}\text { 1. Tingkat teknologi untuk kapal dan alat } \\
\text { tangkap } \\
\text { 2. Teknologi untuk penanganan, pengolahan, } \\
\text { dan preservasi (pelestarian) ikan }\end{array}$ & 1 & 2 & \\
\hline $\begin{array}{l}\text { Pola } \\
\text { penangkapan } \\
\text { ikan yang } \\
\text { menyebar atau } \\
\text { terkonsentrasi }\end{array}$ & $\begin{array}{l}\text { 1. Kegiatan penangkapan ikan bersifat } \\
\text { musiman } \\
\text { 2. Penangkapan ikan dilakukan di lokasi } \\
\text { tertentu saja } \\
\text { 3. Penangkapan ikan dilakukan di perairan } \\
\text { lepas pantai }\end{array}$ & 1 & 2 & \\
\hline
\end{tabular}

1. Tingkat teknologi untuk alat kapal dan alat tangkap tidak memadai. Selama ini atau dalam 7 tahun terakhir nelayan masih menggunakan teknologi lama yaitu perahu bermotor yang kebanyakan belum dilengkapi dengan sonar. Di Kecamatan Sungai Kunyit terdapat 222 kapal motor yang mencakup 73 perahu tempel, 75 kapal motor (0-5 Gt), 76 kapal motor ( > 0-5 Gt). Di Kecamatan Mempawah Hilir terdapat 299 kapal motor yang mencakup 244 perahu tempel, 39 kapal motor (0-5 Gt), 14 kapal motor ( > 0-5 Gt). Di Kecamatan mempawah Timur terdapat 461 kapal motor yang mencakup 176 perahu tempel, 118 kapal motor (0-5 Gt), 167 kapal motor ( > 0-5 Gt). Teknologi untuk penangan ikan lebih mengandalkan ruang pendingin yang diberi es balok.

2. Kegiatan atau pola penangkapan ikan cenderung dilakukan secara musiman yaitu berkisar antara 1- 4 minggu. Penangkapan ikan masih dilakukan di lokasi atau perairan tertentu yaitu di antara pulau-pula, sebab selain tingkat teknologi kapal yang belum memadai juga keterbatasan nelayan dalam batasbatas penangkapan.

3. Pada umumnya nelayan tidak melakukan penangkapan di lepas pantai disebabkan teknologi penangkapan. Keterbatasan pengetahuan dan teknologi ini bisa menjadi sumber potensi kerusakan biota laut.

Dari Tabel 3, dapat dilihat bahwa tingkatan pasar di Kecamatan Sungai Kunyit, Kecamatan Mempawah Hilir, dan Kecamatan Mempawah Timur adalah sebagai berikut:

1. Dari aspek hasil tangkapan 90 persen dijual atau dipasarkan oleh pengumpul melalui agen hingga ke pengecer yang berada di Kuala Mempawah dan sekitarnya. Prosepek pemasaran ikan sangat baik dalam memenuhi permintaan untuk kota Pontianak, dan Sanggau. Bahkan Ikan Merah, ikan Bambangan dan ikan Kerapuh, diekspor hingga ke Malaysia.

2. Jumlah pembeli relatif banyak, hal ini bisa dilihat bahwa 90 persen hasil tangkapan berada di tangan pembeli. Di tingkat lokal sekitar Kabupaten Pontianak ad 4 agen 
Tabel 3. Aspek Pasar Di Kecamatan Sungai Kunyit, Kecamatan Mempawah Hilir, dan Kecamatan Mempawah Timur

\begin{tabular}{|c|c|c|c|c|}
\hline \multirow[t]{2}{*}{ Atribut } & \multirow[t]{2}{*}{ Indikator } & \multicolumn{3}{|c|}{$\begin{array}{l}\text { Tingkatan } \\
\text { Pasar }\end{array}$} \\
\hline & & 1 & 2 & 3 \\
\hline $\begin{array}{l}\text { Perikanan } \\
\text { subsistem atau } \\
\text { komersial }\end{array}$ & $\begin{array}{l}\text { Persentase hasil tangkapan yang dijual atau } \\
\text { dipasarkan }\end{array}$ & 1 & & \\
\hline Struktur pasar & $\begin{array}{l}\text { 1. Jumlah pembeli } \\
\text { 2. Jumlah penjual } \\
\text { 3. Hubungan antara pembeli dan penjual } \\
\text { 4. Pada segmen pasar tertentu wanita lebih } \\
\text { berperan dari pria } \\
\text { 5. Dalam hal apa peran wanita }\end{array}$ & & 2 & $\begin{array}{l}3 \\
3 \\
3\end{array}$ \\
\hline Orientasi pasar & $\begin{array}{l}\text { Ikan atau produk perikanan dijual di pasar lokal, } \\
\text { domestik, atau internasional }\end{array}$ & 1 & & \\
\hline Nilai Produk & $\begin{array}{l}\text { 1. Perkembangan harga ikan } \\
\text { 2. Hubungan harga ikan antar musim, antar } \\
\text { lokasi, dan antar spesies } \\
\text { 3. Tinggi atau rendah nilai jual yang diterima } \\
\text { nelayan } \\
\text { 4. Nilai tambah ekonomi jika ikan dijual dalam } \\
\text { produk alternatif seperti ikan asin, abon, } \\
\text { kerupuk, amplang, dll. }\end{array}$ & 1 & $\begin{array}{l}2 \\
2\end{array}$ & 3 \\
\hline
\end{tabular}

besar dan 59 pengecer. Di Kota Pontianak terdapat 4 agen dan 115 pengecer. Di Kabupaten Sanggau terdapat 3 agen (jumlah pengecer belum diperoleh), dan di Malaysia ada 2 agen yang langsung mendistribusikan ikan ke restoran dan hotel. Sehingga pada musim-musim tertentu bisa kekurangan stock.

3. Jumlah penjual relatif banyak yaitu di Kecamatan Sungai Kunyit terdapat 97 pengusaha/penjual ikan, Kecamatan Mempawah Hilir terdapat 827 pengusaha/ penjual ikan, dan Kecamatan Mempawah Timur terdapat 21 pengusaha/ penjual ikan.

4. Hubungan antara pembeli dan penjual sangat baik di mana hubungan tersebut lebih bermuatan kearifan lokal yaitu saling percaya dan bertanggung jawab atas transaksi perdagangan, dan selama ini tidak ada konflik antara pembeli dan penjual.

5. Pada segmen pasar tertentu, perempuan ikut berperan dalam membuat produk komoditi dari ikan yang memberi nilai tambah lain melalui upaya yang telah dilakukan oleh kelompok perempuan pesisir dalam mengelola ikan menjadi produk abon, ikan asin, amplang, bakso, dan kerupuk. Upaya ini memang perlu mendapat bantuan terutama mesin dan sistem pengepakan yang belum memenuhi kriteria pasar. Saat ini oleh Ketua PKK dan Kantor Pemberdayaan Perempuan Kabupaten Pontianak juga telah dilakukan langkah-langkah 
pemberdayaan perempuan pesisir, hingga produk pengolahan abon dan hasil olahan ikan lainnya telah banyak dikenal oleh masyarakat luas.

6. Orientasi pasar sudah sangat baik, di mana pemasaran selain untuk memenuhi permintaan di Kabupaten Pontianak, juga di Ibu kota Provinsi Kalimantan Barat, Kabupaten Sanggau, dan Ke Malaysia khusus pemasaran Ikan Merah, ikan Bambangan dan ikan Kerapuh. Tentu saja untuk meningkatkan kualitas hasil tangkapan sangat dibutuhkan alat yang representatif guna menjaga kesegaran ikan.

7. Nilai produk mengindikasikan bahwa perkembangan harga ikan sangat kondusif. Di Kecamatan Sungai Kunyit nilai harga ikan laut tahun 2014 mencapai Rp607.750.000,00, Kecamatan Mempawah Timur nilai harga ikan laut tahun $2014 \quad$ mencapai Rp12.140.000.000,00.

8. Hubungan harga ikan antar musim, antar lokasi, dan antar spesies tidak terlalu berpengaruh sebab harga ikan terutama ikan kualitas ekspor tidak terpengaruh oleh musim seperti ikan kakap merah pada musim ikan banyak harganya tetap tinggi yaitu antara Rp39.500,00 $\mathrm{Rp} 47.000,00 / \mathrm{Kg}$.

9. Pada tingkat nelayan harga jual ikan relatif baik yaitu rata-rata 50-75 persen dari harga pasar. Namun rata-rata nelayan sebelum melaut sudah memiliki pinjaman uang dari toko, hingga hasil tangkapan tersisa 10 persen, bahkan sampai pulang pokok.

10. Nilai tambah ekonomi jika ikan dijual dalam produk alternatif seperti ikan asin, abon, kerupuk, amplang, memang menjanjikan atau memiliki prospek baik, terutama produk olahan ikan yang memiliki karakter khas daerah, seperti udang ebi, ikan asin talang, abon, dan lain-lain.

Pada Tabel 4, dapat dilihat bahwa ada 10 kelompok aspek sosial ekonomi pemegang kepentingan sangat pada umumnya tergantung dengan perikanan sebagai sumber utama mencari nafkah. Pemberdayaan masyarakat pesisir khususnya di Kecamatan Mempawah Timur, berpotensi untuk diteruskan dan dikembangkan dengan alasan bahwa adanya keseragaman pemanfaatan sumberdaya, tingginya harapan dan motivasi nelayan untuk tetap mencari ikan sebagai satusatunya sumber ekonomi dalam meningkatkan pendapatan. Sikap positif dan pro aktif nelayan, baik dalam bekerja sama dengan Dinas Perikanan dan Kelautan Kabupaten Pontianak, maupun terhadap pihak luar.

Keberhasilan pengelolaan dengan model co-management ini sangat dipengaruhi oleh kemauan pemerintah untuk mendesentralisasikan tanggung jawab dan wewenang dalam pengelolaan kepada nelayan dan stakeholder lainnya. Oleh karena co-management membutuhkan dukungan secara legal maupun finansial seperti formulasi kebijakan yang mendukung ke arah Co-management, mengijinkan dan mendukung nelayan dan masyarakat pesisir untuk mengelola dan melakukan restrukturisasi peran para pelaku pengelolaan perikanan. 
Tabel 4. Aspek Sosial Ekonomi Pemegang Kepentingan Di Kecamatan Sungai Kunyit, Kecamatan Mempawah Hilir, dan Kecamatan Mempawah Timur

\begin{tabular}{|c|c|c|c|c|}
\hline \multirow[t]{2}{*}{ Atribut } & \multirow[t]{2}{*}{ Indikator } & \multicolumn{3}{|c|}{$\begin{array}{l}\text { Tingkat Sosial } \\
\text { Pemegang } \\
\text { Kepentingan }\end{array}$} \\
\hline & & 1 & 2 & 3 \\
\hline $\begin{array}{l}\text { Keseragaman } \\
\text { Pemanfaatan } \\
\text { Sumberdaya }\end{array}$ & $\begin{array}{l}\text { 1. Jumlah kelompok yang memanfaatkan } \\
\text { sumberdaya } \\
\text { 2. Apa kelompok berbeda menurut agama, } \\
\text { kesejahteraan, alat atangkap, daerah asal, } \\
\text { dan tempat tinggal } \\
\text { 3. Struktur kepemilikan kapal, alat tangkap, } \\
\text { dan teknologi }\end{array}$ & 1 & 2 & 3 \\
\hline $\begin{array}{l}\text { Ketergantungan } \\
\text { pada Perikanan } \\
\text { sebagai sumber } \\
\text { nafkah }\end{array}$ & $\begin{array}{l}\text { 1. Persentase pendapatan rumah tangga yang } \\
\text { berasal dari perikanan } \\
\text { 2. Sumber mata pencaharian lainnya. }\end{array}$ & 1 & 2 & \\
\hline Motivasi & $\begin{array}{l}\text { 1. Motivasi nelayan dan pemegang } \\
\text { kepentingan lainnya dalam memanfaatkan } \\
\text { sumberdaya } \\
\text { 2. Apakah mereka memanfaatkan } \\
\text { sumberdaya untuk tujuan komersial atau } \\
\text { peningkatan pendapatan }\end{array}$ & & 2 & 3 \\
\hline $\begin{array}{l}\text { Sikap terhadap } \\
\text { risiko, inovasi, } \\
\text { dan aksi kolektif }\end{array}$ & $\begin{array}{l}\text { 1. Sikap masyarakat terhadap risiko, inovasi, } \\
\text { dan aksi kolektif: kuat, lemah, atau tidak } \\
\text { ada perbedaan di antara mereka } \\
\text { 2. Apa ada perebedaan sikap di antara } \\
\text { masyarakat. } \\
\text { 3. Adakah mekanisme sosial politik yang } \\
\text { mencegah pengambilan risiko, mencegah } \\
\text { inovasi, dan mencegah aksi kolektif } \\
\text { 4. Jenis aksi kolektif yang dijalankan }\end{array}$ & 1 & 2 & \\
\hline $\begin{array}{l}\text { Tingkat } \\
\text { informasi dan } \\
\text { pengetahuan } \\
\text { tentang } \\
\text { perikanan dan } \\
\text { pengelolaannya }\end{array}$ & $\begin{array}{l}\text { 1. Cara memperoleh informasi sumberdaya } \\
\text { perikanan } \\
\text { 2. Jenis informasi yang tersedia : secara lokal, } \\
\text { atau harus diambil dari luar. } \\
\text { 3. Pengetahuan ilmiah yang dimanfaatkan } \\
\text { oleh masyarakat. }\end{array}$ & $\begin{array}{l}1 \\
1 \\
1\end{array}$ & & \\
\hline
\end{tabular}

Pengelolaan menggabungkan antara pengelolaan sumberdaya yang sentralistis yang selama ini banyak dilakukan oleh pemerintah (government based management) dengan pengelolaan sumberdaya yang berbasis masyarakat

(community

based management). Hirarki tertinggi berada pada tataran hubungan saling kerjasama (cooperation), baru kemudian pada hubungan consultative dan advisory. Hubungan kerjasama yang dilakukan dapat 
mencakup kerjasama antar sektor, antar wilayah, serta antar aktor yang terlibat.

\section{Kerjasama Lintas Sektor}

Pada kawasan pesisir, tidak hanya sektor perikanan yang berperan besar. Sektorsektor lainnya pun memiliki peranan besar karena saling terkait untuk dapat memecahkan permasalahan yang ada. Misalnya saja yang berkaitan dengan perekonomian masyarakat pesisir, sektor industri dan jasa menjadi sektor yang memiliki kontribusi besar dalam pengembangan usaha produktif masyarakat. Yang berkaitan dengan kelestarian lingkungan juga tidak lepas dari peran serta dan keterlibatan sektor industri di mana biasanya limbah industri dibuang ke perairan. Infrastruktur pendukung juga menjadi hal penting untuk dapat mengembangkan wilayah dan menjaga kelestarian lingkungan. Untuk itu, kerjasama lintas sektor sangat perlu diperhatikan karena masing-masing sektor memiliki kepentingannya sendirisendiri. Masing-masing sektor harus saling mendukung. Peran pemerintah daerah dalam hal ini sangat besar agar terjadi sinergi yang baik dalam pengembangan setiap sektor, sehingga tidak ada yang saling merugikan.

2. Kerjasama Antar wilayah

Kawasan pesisir pada dasarnya tidak dapat dibatasi secara administratif. Berkaitan dengan hal ini, maka wilayah yang termasuk dalam suatu kawasan (adanya homogenitas baik secara ekologis maupun ekonomis) haruslah saling bekerjasama untuk meminimalisir konflik kepentingan. Kerjasama antar wilayah dapat digalang melalui pembentukan forum kerjasama atau forum komunikasi antar pemerintah daerah yang memiliki kawasan pesisir dan laut untuk mengantisipasi sejak dini timbulnya perkembangan terburuk seperti konflik antar nelayan. Kesepakatan dan penetapan normanorma kolektif tentang pemanfaatan sumberdaya lokal sesuai dengan semangat otonomi daerah harus disosialisasikan secara luas dan benar kepada masyarakat nelayan agar mereka memiliki cara pandang yang sama.

3. Kerjasama Antar Aktor (stakeholders) Upaya pengurangan kesenjangan sektoral dan daerah jelas memerlukan strategi khusus bagi penanganan secara komprehensif dan berkesinambungan. Untuk itu, diperlukan adanya kebijakan dari Pemerintah Pusat, Pemerintah Provinsi, dan Pemerintah Daerah untuk menjembatani persoalan kemiskinan dan kesenjangan sektoral dan daerah tersebut, melalui mekanisme kerjasama antar aktor (stakeholders) yang melibatkan unsur-unsur masyarakat (kelompok nelayan), pihak swasta/pengusaha perikanan (Private Sector), dan pemerintah (Government). Sebagai anak bangsa yang prihatin melihat kondisi yang menjadi potret buram dalam pengelolaan kawasan pesisir dan laut yang belum memberikan kesejahteraan bagi masyarakatnya tersebut, maka diperlukan perhatian yang serius berupa terobosan pemikiran bagi upaya percepatan pembangunan dan pengembangan ekonomi lokal yang melibatkan partisipasi masyarakat dalam proses dan pelaksanaan pengelolaannya. 
Upaya penanggulangan kemiskinan dan kesenjangan sektoral dan daerah tersebut yang berintikan suatu paradigma baru, di mana inisiatif pembangunan daerah tidak lagi digulirkan dari pusat, namun merupakan inisiatif lokal (daerah) untuk memutuskan langkah-langkah yang terbaik dalam mengimplementasikan rencana pengelolaan kawasan dan rencana aksi yang sesuai dengan kebutuhan dan kapasitas yang dimiliki.

\section{SIMPULAN}

1. Permasalahan umum yang dijumpai dalam kajian dan pengembangan ekonomi masyarakat pesisir di Kecamatan Sungai Kunyit, Kecamatan Mempawah Hilir, dan Kecamatan Mempawah Timur adalah dari aspek biofisik belum adanya batas wilayah tangkap dan kurangnya peralatan modal; dari aspek teknologi penangkapan belum memadai; dari aspek pasar belum adanya manajemen distribusi, belum adanya armada angkut yang dilengkapi dengan cool storage, dan masih rendah modal usaha; dari aspek sosial ekonomi pemegang kepentingan masih rendahnya kualitas sumberdaya manusia; kurangnya sarana dan prasarana; adanya kerusakan fisik habitat; kemiskinan penduduk pesisir; kurangnya pemahaman terhadap nilai sumberdaya; dan masalah kelembagaan. Masalah lain dalam pembangunan dan pengembangan wilayah pesisir adalah kurangnya pelibatan masyarakat dalam perencanaan, pemanfaatan dan pengelolaan wilayah pesisir, sehingga program-program di wilayah pesisir tidak dapat berjalan secara optimal.

2. Berdasarkan hasil analisis pada wilayah studi bahwa komponen weaknesses menempati urutan teratas dalam program pemberdayaan masyarakat pesisir, kemudian diikuti berturut-turut oleh komponen threats, strength dan opportunities. Hal tersebut menunjukkan bahwa program pemberdayaan masyarakat pesisir mempunyai kelemahan dan tantangan yang besar jika dibandingkan dengan kekuatan dan peluangnya.

3. Faktor-faktor internal yang mempengaruhi pemberdayaan masyarakat pesisir mencakup faktorfaktor kekuatan dan kelemahan. Faktorfaktor kekuatan yang paling utama adalah banyaknya jumlah nelayan dan pembudidaya yang diberdayakan; potensi kelautan dan perikanan, khususnya di Kabupaten Pontianak masih tinggi; potensi lahan budidaya tambak dan laut masih luas; dan banyaknya kearifan lokal yang mendukung pemberdayaan. Sedangkan faktor-faktor kelemahan yang paling utama adalah kualitas SDM masyarakat pesisir masih sangat rendah; sarana dan prasarana perikanan dan kelautan masih rendah; degradasi sumberdaya alam dan lingkungan pesisir dan laut; kurangnya modal dalam usaha perikanan; dan kapasistas kelembagaan masyarakat pesisir masih rendah.

4. Faktor-faktor eksternal yang mempengaruhi adalah faktor peluang dan ancaman. Faktor-faktor peluang mencakup adanya perhatian dari 
pemerintah cukup tinggi; peluang pendanaan pemberdayaan masih banyak; dan permintaan produk perikanan dalam dan luar masih tinggi. Sedangkan faktor-faktor ancaman adalah prioritas pembangunan sektor perikanan lebih rendah dari sektor lain; adanya pencemaran limbah industri, pertanian dan rumah tangga; tingginya pencurian ikan; dan adanya tekanan kelembagaan nelayan tradisional seperti juragan/tengkulak.

5. Berdasarkan faktor-faktor internal dan eksternal pada lokasi studi kebijakan pengembangan dilakukan melalui pemberdayaan masyarakat pesisir sesuai dengan peringkatnya/ prioritasnya adalah sebagai berikut: (a) peningkatan kesejahteraan masyarakat pesisir; (b) peningkatan kualitas sumberdaya manusia; dan (3) konservasi dan perlindungan sumberdaya kelautan dan perikanan (SDKP).

6. Prioritas program pemberdayaan masyarakat pesisir sesuai dengan urutannya adalah sebagai berikut: (1) pemberdayaan masyarakat berbasis perikanan tangkap pada wilayah yang sudah terjadi over fishing; (2) pemberdayaan masyarakat berbasis budidaya pada wilayah yang sumberdaya yang lahannya terbatas; (3) pemberdayaan masyarakat pada wilayah yang terjadi degradasi sumberdaya alam dan pencemaran lingkungan; (4) pemberdayaan masyarakat pada kawasan konservasi dan pariwisata bahari; (5) pemberdayaan masyarakat pesisir berbasis perikanan tangkap pada wilayah yang sumberdayanya masih melimpah; dan (6) pemberdayaan masyarakat berbasis budidaya pada wilayah yang sumberdayanya masih tinggi.

Beberapa saran yang dapat diajukan adalah:

1. Seyogyanya pengelolaan wilayah pesisir perlu mengatasi komponen, pertama: weaknesses dengan cara memperbaiki atau memperbaharui dan menambah peralatan tangkap, pengelolaan manajemen perikanan, memberikan bantuan modal dan pelatihan manajemen keuangan, memberikan pendidikan dan keterampilan nelayan dalam pengelolaan sumberdaya ikan, memperbaiki pemukiman nelayan, bantuan akses pasar, dan membentuk kelembagaan ekonomi oleh dan untuk nelayan. Kedua, threats dengan cara memanaj biaya pengelolaan sumber daya, kemampuan akses pasar, penangkapan illegal oleh kapal asing, mengawasi penggunaan jaring cantrang, kelestarisan lingkungan, dan menambah jumlah armada pengawasan. Ketiga, strength yaitu penguatan keinginan masyarakat untuk mandiri dan penguatan kelompok ekonomi masyarakat pesisir produktif, pengelolaan dan pemasaran keberagaman ikan, penguatan keamanan wilayah pesisir. Keempat, opportunities penguatan pada potensi pasar, pertumbuhan tingkat pendapatan, potensi sumber daya kelautan dan pesisir, dan penguatan perkembangan bisnis perikanan yang semakin baik 
2. Agar pemberdayaan di wilayah pesisir tetap berkelanjutan, maka pemerintah hendaknya bekerjasama dengan swasta atau BUMN dari sejak mulai dilaksanakan. Kemitraan tersebut mulai dari aspek pendanaan, bantuan teknis, manajemen, dalam bidang penyediaan input, pemasaran produk perikanan, dan pengolahan produk perikanan. Sehingga "proyek" pemberdayaan ini tidak berhenti setelah pemberdayaan dari pemerintah selesai.

3. Prasyarat efektivitas pemberdayaan masyarakat menuntut kepastian substansi sistem hukum yang berlaku. Selain itu juga perlunya kegiatan fasilitasi melalui suatu upaya pendampingan secara bertahap, sesuai dengan tingkat kesiapan atau kematangan masyarakat setempat. Dalam hal ini, pendampingan lebih berorientasi kepada pengembangan keswadayaan dan kemandirian berbasis pada potensi, permasalahan dan kebutuhan masyarakat. Metode yang relatif sesuai dalam hal ini adalah pendekatan yang bersifat partisipatif.

4. Pengembangan melalui pemberdayaan ekonomi masyarakat pesisir, seyogyanya dilakukan secara terpadu dalam suatu lokasi, baik antara masyarakat dengan pemerintah melalui pendekatan pengelolaan yang berbasis wilayah. Program pemberdayaan tersebut seharusnya disesuaikan dengan permasalahan dan potensi sumberdaya manusia dan sumberdaya alam di wilayah tersebut sehingga permasalahan dalam suatu wilayah dapat diatasi.
5. Program pemberdayaan seyogyanya dilakukan berdasarkan pendekatan wilayah dan hanya pada wilayah-wilayah tertentu saja di mana potensi sumberdaya alamnya masih banyak, jumlah masyarakatnya yang miskin masih banyak dan dilakukan uji coba selama 2 - 3 tahun, kemudian setelah berhasil baru program tersebut disosialisakan pada wilayah-wilayah pesisir lainnya.

6. Pola pemberdayaan masyarakat seyogyanya diserahkan kepada kewenangan daerah, namun daerah juga harus menerapkan prinsip-prinsip pemberdayaan, yang lebih bersifat partisipatif, desentralistik terhadap kemampuan komunitas dan berorientasi pada hasil. Kewenangan Pusat lebih pada supervisi dan perencanaan serta kebijakan makro dan pengembangan prinsip-prinsip pemberdayaan baik secara teknis maupun non teknis yang dapat dijadikan sebagai rambu-rambu yang jelas bagi daerah didalam pemberdayaan masyarakat. Sedangkan daerah perlu mendapat kewenangan serta sepenuhnya bertanggungjawab atas kewenangan itu dengan sistem hukum dengan penegakan sanksi yang jelas.

\section{DAFTAR PUSTAKA}

A. Muluk, Alains., Seprianti Eka Putri., Prilia Haliawan. (2009) Pengelolaan Sumberdaya Perikanan Berbasis Masyarakat (PSPBM) melalui Model CoManagement Perikanan. Jurnal Ekonomi Pembangunan 10(2), 172 - 198 
Agus, Apun, Budhiman., Hary, Christijanto., Siti., Kamarijah, Ganef, Hari, Budoyo. (2010) Penentuan Insikator Pendekatan Ekosistem Dalam Pengelolaan Perikanan (Ecosystem Approach to Fisheries Management). Bogor: Direktorat Sumberdaya Ikan, Direktorat Jenderal Perikanan Tangkap, Kementerian Kelautan dan Perikanan, WWF-Indonesia dan Pusat Kajian Sumberdaya Pesisir dan Lautan Institut Pertanian Bogor.

Arifin, Rudyanto (2004) Kerangka Kerjasama dalam Pengelolaan Sumberdaya Pesisir dan Laut. Jakarta: Bappenas.

Berkes, F., Folke, C. (Eds.), (1998) Linking Social and Ecological Systems, Management Practices and Social Mechanisms for Building Resilience. Cambridge University Press, Cambridge.

Berkes, F., Folke. Evolution of comanagement: Role of knowledge generation, bridging organizations and social learning. Journal of Environmental Management 90 (2009) 1692-1702

Carlssona, Lars \& Berkesb Fikret. (2005) Comanagement: concepts and methodological implications. Journal of Environmental Management 75, 65-76

Cundill, Georgina \& Christo Fabricius. (2009) Monitoring in adaptive co-management: Toward a learning based approach. Journal of Environmental Management 90, 3205-3211
Grazia Borrini-Feyerabend., M. Taghi Farvar., Jean Claude Nguinguiri and Vincent Awa Ndangang. (2007). Co-management of Natural Resources Organising, Negotiating and Learning-by-Doing. Heidelberg (Germany): Reprint 2007 [first publication)

Lembaga Survey dan Kajian Kalimantan Barat 2013

Luky Adrianto \& Dede Hartoto (2009) Fundamentals of fisheries comanagement in Indonesia. Course book. Rome, Italy : Electronic Publishing Policy and Support Branch Communication Division

Nies, Suk. (2000) Pemecahan Masalah dan Pengambilan Keputusan. Lembaga dministrasi Negara Republik Indonesia. LAN. Jakarta.

Putusan Mahkamah Konstitusi No 3/PUUVIII/2010, h, 164-165

Singleton, S. (1998) Constructing Cooperation: the Evolution of Institutions of Comanagement. University of Michigan Press, Ann Arbor.

Suseno. (2007) Menuju Perikanan Berkelanjutan. Cetakan Pertama. Jakarta: Penerbit Pustaka Cidesindo.

Sweeden, Paula., Batker Deve., RadtkeHans., Boumans Roelof., Willer Chuck. (2008) An Ecological Economics Approach to Understanding Oregon's Coastal Economy and Environment. Oregan: Coast Range Association. $h, 37$ 